\title{
NILAI-NILAI PENDIDIKAN BERBASIS KARAKTER PADA PENDIDIKAN DASAR DAN MENENGAH
}

Oleh:

Dra. Mardiah Baginda, M.PdI

\begin{abstract}
ABSTRAK
Pemerintah telah menggalakkan pentingnya pendidikan karakter bagi siswa di sekolah.Berbagai program yang dicanangkan oleh pemerintah dalam upaya diimplementasikan pendidikan karakter.Kementerian Pendidikan Nasional sudah mencanangkan penerapan pendidikan karakter untuk semua tingkat pendidikan dari SD sampai Perguruan Tinggi.

Kesimpulan: 1) Nilai-nilai pendidikan karakter bagi siswa Sekolah dasar dan menengah yaitu: Religius, jujur, toleransi, disiplin, Kerja Keras, Kreatif, Mandiri, Demokratis, Rasa Ingin Tahu, Semangat Kebangsaan, Cinta Tanah Air, Menghargai Prestasi, Bersahabat/Komunikatif, Cinta Damai, Gemar Membaca, Peduli Lingkungan, Peduli Sosial.Tanggung Jawab. 2) Strategi dalam menanamkan nilai-nilai pendidikan karakter bagi siswa Sekolah dasar dan menengah yaitu: Memasukkan pendidikan karakter ke dalam semua mata pelajaran di sekolah, Membuat slogan-slogan atau yel-yel yang dapat menumbuhkan kebiasaan semua masyarakat sekolah untuk bertingkah laku yang baik, Membiasakan perlaku yang positif di kalangan warga sekolah, dan Melakukan pemantauan secara kontinyu, Memberikan hadiah (reward) kepada siswa yang selalu berkarakter baik.

Rekomendasi: 1) Peran seorang kepala sekolah yang mempunyai kompetensi akademik, dimana dapat menyusun program-program yang berkaitan dengan penanaman nilai-nilai pendidikan karakter bagi anak sekolah dasar dan menengah. 2) Guru harus memasukkan targettarget karakter dalam setiap mata pelajaran, sehingga dalam proses pembelajaran guru tidak hanya fokus pada materi-materi yang bersifat kognitif, akan tetapi bagaimana nilai-nilai karakter yang harus ditanamkan pada siswa sekolah dasar dan menengah.
\end{abstract}

\section{Kata Kunci: pendidikan, Karakter, Siswa}




\section{BAB I \\ PENDAHULUAN}

\section{A. Latar Belakang}

Undang-Undang Republik Indonesia nomor 20 tahun 2003 tentang Sistem Pendidikan Nasional (UU Sisdiknas) merumuskan fungsi dan tujuan pendidikan nasional yang harus digunakan dalam mengembangkan upaya pendidikan di Indonesia. Pasal 3 UU Sisdiknas menyebutkan, "Pendidikan nasional bertujuan untuk mengembangkan potensi peserta didik agar menjadi manusia yang beriman dan bertakwa kepada Tuhan Yang Maha Esa, berakhlak mulia, sehat, berilmu, cakap, kreatif, mandiri, dan menjadi warga negara yang demokratis serta bertanggung jawab".

Tujuan pendidikan mengisyaratkan bahwa core value pembangunan masyarakat Indonesia bersumber pada nilai-nilai ketuhanan dan akhlak mulia, yang bermakna bahwa pendidikan nilai merupakan bagian yang penting dalam sistem pengajaran di Indonesia.Namun kenyataannya, sampai saat ini masih marak isu tentang merosotnya nilainilai moral di kalangan pelajar. Aksi tawuran antar-pelajar yang menimbulkan korban dan merusak lingkungan, perbuatan asusila terhadap siswa lain, kecurangan dalam ujian nasional yang marak akhir-akhir ini adalah contoh kongkret telah bergesernya nilai-nilai budaya dan sosial di kalangan pelajar (Priyono, Abu, Ahmadi, 2006 : 48).

Akar permasalahannya adalah belum dimaksimalkan pembentukan nilai-nilai moral dalam proses pembelajaran di sekolah. Berdasarkan kurikulum pendidikan dasar dan menengah sampai pada saat ini untuk pengetahuan umum cenderung berbicara tentang penanaman nilai-nilai moral pda siswa terutama untuk mata pelajaran pendidikan agama dan kewarganegaraan.Namun belum terlihat perubahan yang signifikan dari penanamn nilai-nilai moral melalui pendidikan agama dan kewarganegaraan.Indikasinya terlihat masih banyak siswa yang mempunyai moral yang rendah, seperti contoh: banyak siswa yang suka ikut tawuran, terlibat dalam penggunaan obat-obat terlarang dan lain sebagainya.

Dalam konteks memahami fenomena ini, menarik apa yang disarankan UNESCO bahwa pendidikan harus mengandung tiga unsur :

1. Belajar untuk tahu (learn to know)

2. Belajar untuk berbuat (learn to do) dan

3. Belajar untuk hidup bersama (learn to live together).

Unsur pertama dan kedua lebih terarah membentuk keinginan, agar sumberdaya manusia mempunyai kualitas dalam pengetahuan dan keterampilan atau skill. Unsur ketiga lebih terarah being menuju pembentukan karakter, misalnya; menghargai perbedaan pendapat, tidak memaksakan kehendak, pengembangan sensitivitas sosial dan lingkungan dan sebagainya (Elmubarok,2008: 67).

Fenomena sekarang ini pemerintah telah menggalakkan pentingnya pendidikan karakter bagi siswa di sekolah.Berbagai program yang dicanangkan oleh pemerintah dalam upaya diimplementasikan pendidikan karakter.Kementerian Pendidikan Nasional sudah mencanangkan penerapan pendidikan karakter untuk semua tingkat pendidikan dari SD sampai Perguruan Tinggi. Menurut Muhammad Nuh (Sri Narwani, 2011: 1) pembentukan karakter perlu dilakukan sejak usia dini. Jika karakter sudah terbentuk sejak usia dini maka tidak akan mudah untuk mengubah karakter seseorang. Ia juga berharap, pendidikan karakter dapat membangun kepribadian bangsa. Usia sekolah dasar (sekitar umur 6 - 12 tahun) merupakan tahap penting bagi pelaksanaan pendidikan karakter, bahkan hal yang 
fondamental bagi kesuksesan perkembangan karakter peserta didik. Sigit Dwi K. (2007: 121) menyatakan anak sekolah dasar mengalami perkembangan fisik dan 2 motorik tak terkecuali perkembangan kepribadian, watak emosional, intelektual, bahasa, budi pekerti, dan moralnya yang bertumbuh pesat.

Bertitik tolak dari uraian diatas maka betapa penting pendidikan karakter bagi anakanak.Untuk itu anak-anak yang berada pada pendidikan dasar dan menengah menjadi prioritas utama untuk penanaman nilai-nilai karakter moral yang baik. Pada usia ini merupakan usia dimana pada tahap perkembangan anak membutuhkan informasi-informasi yang baik, berkaitan dengan pembentukan karakter anak. Dengan karakter yang baik maka akan berpengaruh terhadap interaksi anak tersebut di masyarakat. Pembawaan dengan karakter yang baik maka mudah untuk diterima di lingkungan dimana anak tersebut berada. Kaidah-kaidah moralitas di masyarakat sangat erat kaitannya dengan karakter yang baik dari masyarakat itu sendiri termasuk juga, pembentukan karakter bagi anak-anak itu sendiri.

Oleh karena itu jika menghendaki pendidikan karakter dapat berhasil maka pelaksanaannya harus dimulai sejak masa kanak-kanak dan usia SD. Banyaknya tindakan amoral yang dilakukan peserta didik seperti mencontek, tawuran, membolos dan tindakan lainnya mengindikasikan bahwa pendidikan formal gagal dalam membentuk karakter peserta didik. Sjarkawi (2006: 45) menyatakan bahwa perilaku dan tindakan amoral disebabkan oleh moralitas yang rendah. Moralitas yang rendah antara lain disebabkan oleh pendidikan moral di sekolah yang kurang efektif.

Pendidikan Kewarganegaraan merupakan salah satu konsep pendidikan yang berfungsi untuk membentuk siswa sebagai warga negara yang mempunyai karakter.Keterkaitan Pendidikan Kewarganegaraan terhadap pengembangan karakter dikemukakan oleh Samsuri (2011: 20) yang menyatakan Pendidikan Kewarganegaraan memiliki dimensi-dimensi yang tidak bisa dilepaskan dari aspek pembentukan karakter dan moralitas publik warga negara.Tujuan Pendidikan Kewarganegaraan di sekolah dasar tidak hanya sekedar membekali siswa ke jenjang selanjutnya tetapi penanaman moral yang diharapkan dapat membentuk warga negara yang baik.

Sumiyati (2008: 1) menyatakan bahwa PKn sebagai pendidikan nilai, moral, dan norma tetap ditanamkan pada siswa sejak usia dini, karena jika siswa sudah memiliki nilai 3 moral yang baik, maka tujuan untuk membentuk warga negara yang baik akan mudah diwujudkan. Sebagaimana yang dikemukakan sebelumnya, dalam prakteknya PKn menghadapi kendala yang mengakibatkan jauhnya tujuan pembelajaran. Pernyataan dari kelemahan PKn diungkapkan oleh Udin S. Winataputra (2009: 37) yang menyatakan bahwa proses pembelajaran dan penilaian lebih menekankan pada dampak instruksional yang terbatas pada penguasaan materi/pada dimensi kognitif. Dengan demikian apa yang diperoleh peserta didik bukan bersifat kognitif, afektif, dan psikomotorik namun masih dalam lingkup kognitif.

Dari uraian diatas maka jelas terlihat bahwa kelemahan mata pelajaran seperti Pendidikan Agama dan PKn lebih difokuskan pada masalah kognitif. Artinya berkaitan dengan pengetahuan siswa tentang mata pelajaran tersebut, namun kurang untuk memberikan pembekalan apa-apa yang harus mereka lakukan ketika berhadapan dengan dunia nyata, dimana akan bertemu dengan semua orang yang ada di masyarakat. Melalui Kesempatan ini penulis ingin menguraikan tentang target-target karakter yang harus menjadi dasar untuk pembentukan karakter anak pada siswa di sekolah dasar dan menengah. Target karakter tersebut akan diuraikan dalam bentuk nilai-nilai karakter, hal ini sangat penting 
mengingat penanaman selama ini tidak fokus pada nilai-nilai karakter apa yang dapat ditanamkan terhadap siswa pada Sekolah dasar dan menengah.

\section{B. Rumusan Penulisan}

1. Bagaimanakah nilai-nilai karakter yang harus ditanamkan pada Siswa di Sekolah Dasar dan Menengah?

2. Bagaimanakah strategi untuk menanamkan nilai-nilai karakter pada siswa di Sekolah dasar dan menengah?

\section{Tujuan Penulisan}

1. Untuk mengetahui nilai-nilai karakter yang harus ditanamkan pada Siswa di Sekolah Dasar dan Menengah.

2. Untuk mengetahui strategi untuk menanamkan nilai-nilai karakter pada siswa di Sekolah dasar dan menengah.

\section{Manfaat Penulisan}

1. Untuk menambah pengetahuan tentang pendidikan khususnya pada nilai-nilai karakter yang harus ditanamkan kepada siswa.

2. Untuk menambah pengetahuan tentang pendidikan khususnya strategi penanaman nilainilai karakter bagi siswa.

3. Sebagai bahan rujukan untuk meneliti atau menulis tentang pendidikan karakter 


\section{BAB II \\ PEMBAHASAN}

\section{A. Pendidikan Karakter}

Karakteristik berasal dari kata "characteristic" yang berarti sifat yang khas. Atau bisa diambil pengertian bahwa karakteristik adalah suatu sifat khas yang membedakan dengan yang lain.Karakter adalah wujud pemahaman dan pengetahuan seseorang tentang nilai-nilai mulia dalam kehidupan yang bersumber dari tatanan budaya, agama dan kebangsaan seperti : nlai moral, nilai etika, hukum, nilai budi pekerti, kebajikan dan syari'at agama dan budaya serta diwujudkan dalam sikap, perilaku dan kepribadian sehari-hari hingga mampu membedakan satu dengan lainnya. Dengan demikian maka karakter pada hakekatnya bukan hanya harus dipahami dan diketahui ataupun hanya diajarkan tetapi harus diteladani. Dimana yang selanjutnya diharapkan bahwa karakter individu tersebut akan membangun karakterkarakter daerah dan bangsa sesuai dengan harapan dan cita-cita luhur dalam tujuan pendidikan nasional. Pendapat lain dari pengertian karakter, seperti yang disampaikan Gunarto (2004 : 22) bahwa : Karakter merupakan nilai-nilai perilaku manusia yang berhubungan dengan Tuhan Yang Maha Esa, diri sendiri, sesama manusia, lingkungan, dan kebangsaan yang terwujud dalam pikiran, sikap, perasaan, perkataan, dan perbuatan berdasarkan norma-norma agama, budaya dan nilai kebangsaan yang diaktualisasikan dalam kehidupan sehari-sehari menjadi suatu pembiasaan yang melekat.

Menurut UU No. 20 tahun 2003 tentang sistem pendidikan nasional, dinyatakan bahwa : Pendidikan adalah usaha sadar dan terencana untuk mewujudkan suasana belajar dan proses pembelajaran agar peserta didik secara aktif mengembangkan potensi dirinya untuk memiliki kekuatan spiritual keagamaan, pengendalian diri, kepribadian, kecerdasan, akhlak mulia, serta keterampilan yang diperlukan dirinya, masyarakat, bangsa dan negara. Pendidikan karakter adalah pendidikan budi pekerti plus, yaitu yang melibatkan aspek pengetahuan (cognitive), perasaan (feeling), dan tindakan (action), tanpa ketiga aspek ini, maka pendidikan karakter tidak akan efektif dan pelaksanaannya pun harus dilakukan secara sistematis dan berkelanjutan serta mampu membedakan satu dengan lainnya. Dengan pendidikan karakter, seorang anak akan menjadi cerdas emosinya. Hal ini sesuai dengan pendapat Daniel (2007 : 89) tentang "Keberhasilan seseorang di masyarakat, ternyata 80\% dipengaruhi oleh kecerdasan emosi (EQ), dan hanya 20\% ditentukan oleh kecerdasan otak (IQ)". Dalam kajian tersebut dibahas delapan pendekatan pendidikan nilai berdasarkan kepada berbagai literatur dalam bidang psikologi, sosiologi, filosofi dan pendidikan yang berhubungan dengan nilai. Namun, selanjutnya berdasarkan kepada hasil pembahasan dengan para pendidik dan alasan-alasan praktis dalam penggunaannya di lapangan, pendekatan-pendekatan tersebut telah diringkas menjadi lima jenis pendekatan berikut : Lima pendekatan tersebut adalah :

1. Pendekatan penanaman nilai (inculcation approach)

2. Pendekatan perkembangan moral kognitif (cognitive moral development approach)

3. Pendekatan analisis nilai (values analysis approach)

4. Pendekatan klarifikasi nilai (values clarification approach); dan

5. Pendekatan pembelajaran berbuat (action learning approach). (Superka, 2006 : 78).

Pendidikan adalah usaha sadar dan terencana untuk mewujudkan suasana belajar dan proses pembelajaran agar peserta didik secara aktif mengembangkan potensi dirinya untuk 
memiliki kekuatan spiritual keagamaan, pengendalian diri, kepribadian, kecerdasan, akhlak mulia, serta keterampilan yang diperlukan dirinya, masyarakat, bangsa dan negara.

Karakter adalah sifat khas, kualitas dan kekuatan moral pada seseorang atau kelompok. Puskur (Pusat Kurikulum) memberikan suatu definisi atau pengertian karakter sebagai watak tabiat, akhlak, ataukepribadian seseorang yang terbentuk dari hasil internalisasi nilai-nilai kebajikan yang dapat menjadi suatu keyakinan dandigunakannya sebagai landasan cara pandang, berpikir, bersikap, dan bertindak.

Pendidikan karakter adalah usaha sadar dan terencanadalam menanamkan nilai-nilai sehingga terinternalisasi dalam diri peserta didik yang mendorong dan mewujud dalam sikap dan perilaku yang baik.Pendidikan karakter bukan terletak pada materi pembelajaran melainkan pada aktivitas yang melekat, mengiringi, dan menyertainya (suasana yang mewarnai, tercermin dan melingkupi proses pembelajaran pembiasaan sikap dan perilaku yang baik) Pendidikan karakter tidak berbasis pada materi, tetapi pada kegiatan.

Proses terbentuknya pendidikan karakter (Tim Pengembangan FIP-UPI. 2007 : 4), yaitu :

1. Melalui pendidikan, pengalaman, cobaan hidup, pengorbanan dan pengaruh lingkungan,kemudian terinternalisasi nilai-nilai sehingga menjadi nilai intrinsik yang melandasi sikap dan perilaku.

2. Sikap dan perilaku tersebut dilakukan berulang-ulang sehingga menjadi kebiasaan.

3. Kebiasaan tersebut dijaga dan dipelihara maka jadilah karakter

Jadi bahwa keberhasilan dalam proses pembentukan karakter lulusan suatu satuan pendidikan, akan ditentukan bukan oleh kekuatan proses pembelajaran, tetapi akan ditentukan oleh kekuatan manajemennya, yang mengandung pengertian bahwa mutu karakter lulusan memiliki ketergantungan kuat terhadap kualitas manajemen sekolahnya. Hal ini disebabkan karena proses pembentukan karakter harus terintegrasi kedalam berbagai bentuk kegiatan sekolah.

\section{B. Manajemen Pendidikan Karakter}

Manajemen pendidikan karakter di lingkungan sekolah merupakan program yang berkesinambungan dan terintegrasi kedalam keseluruhan sistem pengelolaan pendidikan. Hal ini didasarkan kepada : tujuan pendidikan nasional, yakni membentuk manusia seutuhnya. Penulisan ini akan mencoba membahas permasalahan manajemen sekolah berbasis karakter, yakni sistem pengelolaan sekolah yang mengintegrasikan nilai-nilai karakter kepada keseluruhan tatanan kehidupan dan pengelolaan pendidikan, dengan isu sentral bahwa implementasi manajemen sekolah berbasis karakter membutuhkan strategi implementasi, kesiapan SDM, penentuan indikator keberhasilan, desain implementasi, strategi evaluasi, analisis hambatan yang dihadapi dan analisis terhadap kebutuhan kebijakan implementasi manajemen sekolah berbasis karakter.

Manajemen sekolah Berbasis Karakter (MSBK) dalam kajian penulisan ini hakekatnya, sebuah proses pengelolaan berbagai kegiatan pengelolaan pendidikan di lingkungan sekolah yang disertai dengan komitmen tinggi pada setiap pelaku dan perilaku pengelola dengan menanamkan nilai-nilai karakter mulia sehingga secara langsung mendukung keberhasilan proses pendidikan karakter dan pembelajaran, sehingga menghasilkan produktivitas mutu lulusan yang berkarakter mulia sesuai dengan tuntutan tujuan pendidikan nasional. Komponen sasaran dalam sistem manajemen sekolah yang tidak mengindahkan nilai-nilai karakter atau menunjang keberhasilan pembentukan karakter 
peserta didik.Dua kelompok kajian pustaka yang mendukung terhadap kajian penulisan ini, adalah kajian konsep pendidikan karakter dan konsep manajemen sekolah berbasis karakter.

Karakter adalah wujud pemahaman dan pengetahuan seseorang tentang nilai-nilai mulia dalam kehidupan yang bersumber dari tatanan budaya, agama dan kebangsaan seperti : nilai moral, nilai etika, hukum, nilai budi pekerti, kebajikan dan syari'at agama dan budaya serta diwujudkan dalam sikap, perilaku dan kepribadian sehari-hari hingga mampu membedakan satu dengan lainnya. Dengan demikian maka karakter pada hakekatnya bukan hanya harus dipahami dan diketahui ataupun hanya diajarkan tetapi harus diteladani. Dimana yang selanjutnya diharapkan bahwa karakter individu tersebut akan membangun karakterkarakter daerah dan bangsa sesuai dengan harapan dan cita-cita luhur dalam tujuan pendidikan nasional. Pendapat lain dari pengertian karakter, seperti yang disampaikan Gunarto (2004 :22) bahwa : Karakter merupakan nilai-nilai perilaku manusia yang berhubungan dengan Tuhan Yang Maha Esa, diri sendiri, sesama manusia, lingkungan, dan kebangsaan yang terwujud dalam pikiran, sikap, perasaan, perkataan, dan perbuatan berdasarkan norma-norma agama, budaya dan nilai kebangsaan yang diaktualisasikan dalam kehidupan sehari-sehari menjadi suatu pembiasaan yang melekat.

Manajemen Sekolah Berbasis Karakter (MSBK). Berkenaan dengan pengertian manajemen sekolah berbasis karakter yang memungkinkan dilakukan di tingkat sekolah, maka Culberston (2010 : 122), mengemukakan bahwa : Some characteristics of the school management process of character in an school unit, which are :

1. Integrate the values of the characters in the whole school management activities

2. Integrating the values of the characters in the overall school performance activity

3. Integrating the value-character value to the overall performance of personnel activities

4. Integrate the values of the characters on the overall activities of educational services; and

5. Integrating the values of the characters in the whole learning activities.

Kutipan tersebut menjelaskan bahwa : Beberapa karakteristik dari proses manajemen sekolah yang berkarakter mulia pada suatu satuan pendidikan, diantaranya adalah :

1. Mengintegrasikan nilai-nilai karakter pada keseluruhan kegiatan manajemen sekolah

2. Mengintegrasikan nilai-nilai karakter pada keseluruhan kegiatan kinerja sekolah

3. Mengintegrasikan nilai-nilai karakter pada keseluruhan kegiatan kinerja personil

4. Mengintegrasikan nilai-nilai karakter pada keseluruhan kegiatan layanan pendidikan

5. Mengintegrasikan nilai-nilai karakter pada keseluruhan kegiatan pembelajaran.

Hal lain yang menunjang secara rasional implementasi MSBK seperti yang dinyatakan oleh Hoover (2003 : 46), menyatakan bahwa : Success in the process of forming the character of an educational unit graduates, will be determined not by the strength of the learning process, but will be determined by the strength of its management, which implies that the quality of graduates character has a strong dependence on the quality of school management. This is because the process of character formation should be integrated into various forms of school activitie.

Jadi bahwa keberhasilan dalam proses pembentukan karakter lulusan suatu satuan pendidikan, akan ditentukan bukan oleh kekuatan proses pembelajaran, tetapi akan ditentukan oleh kekuatan manajemennya, yang mengandung pengertian bahwa mutu karakter lulusan memiliki ketergantungan kuat terhadap kualitas manajemen sekolahnya. Hal ini disebabkan karena proses pembentukan karakter harus terintegrasi kedalam berbagai bentuk kegiatan sekolah. Berdasarkan paparan tersebut, maka untuk menunjang keberhasilan 
proses pembentukan karakter peserta didik melalui pendidikan berbasis karakter, harus ditunjang dengan implementasi manajemen sekolah berbasis karakter, yakni sistem pengelolaan dan penyelenggaraan pendidikan dengan menginternalisasikan dan mengintegrasikan nilai-nilai karakter pada :

1. Setiap komponen manajemen sekolah (input, proses dan output/outcome)

2. Pada proses perencanaan, pengorganisasian, implemen-tasi, pengawasan dan evaluasi manajemen sekolah; dan

3. Pada sasaran kinerja sekolah, yakni pengelolaan (kurikulum dan pembelajaran, peserta didik, ketenagaan, keuangan, sarana prasarana, administrasi, keorganisasian, peran masyarakat, dan lingkungan, iklim serta budaya) berbasis karakter.

Pendidikan karakter menggarap pelbagai aspek dari pendidikan moral, pendidikan kewargaan, dan pengembangan karakter.Sifatnya yang multi-faceted membuatnya menjadi konsep yang sulit untuk diberikan di sekolah. Setiap komponen memberikan perbedaan tekanan tentang apa yang penting dan apa yang semestinya diajarkan. "Jika kita hendak maju secara budaya", kata Rushworth Kidder (1995 : 132) dari the Institute for Global Ethics, dan pengarang How Good People Make Tough Choices "sepatutnya mesti ada satu bahasa lagi dalam wacana public, yang mempertanyakan, "apa yang benar" (what's right)? " Menurutnya, bahasa ini merupakan bahasa yang unik yang membuat kita tak terlalu nyaman membincangkannya. Dan untuk membuat kita nyaman berbincang dalam bahasa ini di masa depan, Kidder menekankan perlunya pendidikan karakter sejak dini. Ada 18 (delapan belas) nilai-nilai dalam pengembangan pendidikan karakter bangsa yang dibuat oleh Diknas.

Mulai tahun ajaran 2011, seluruh tingkat pendidikan di Indonesia harus menyisipkan pendidikan berkarakter tersebut dalam proses pendidikannya (Risna .A dan Siti .N, 2011 : 1). Ada 18 (delapan belas) nilai-nilai dalam pendidikan karakter menurut Kementerian Pendidikan Nasional (2013), adalah :

1. Religius.

Sikap dan perilaku yang patuh dalam melaksanakan ajaran agama yang dianutnya, toleran terhadap pelaksanaan ibadah agama lain, dan hidup rukun dengan pemeluk agama lain.

2. Jujur.

Perilaku yang didasarkan pada upaya menjadikan dirinya sebagai orang yang selalu dapat dipercaya dalam perkataan, tindakan, dan pekerjaan.

3. Toleransi.

Sikap dan tindakan yang menghargai perbedaan agama, suku, etnis, pendapat, sikap, dan tindakan orang lain yang berbeda dari dirinya.

4. Disiplin.

Tindakan yang menunjukkan perilaku tertib dan patuh pada berbagai ketentuan dan peraturan.

5. Kerja Keras.

Tindakan yang menunjukkan perilaku tertib dan patuh pada berbagai ketentuan dan peraturan.Jadi dengan peirlaku tertib ini dapat membangun karakter siswa dalam kehidupan nyata.

6. Kreatif.

Berpikir dan melakukan sesuatu untuk menghasilkan cara atau hasil baru dari sesuatu yang telah dimiliki.

7. Mandiri. 
Sikap dan perilaku yang tidak mudah tergantung pada orang lain dalam menyelesaikan tugas-tugas.

8. Demokratis.

Cara berfikir, bersikap, dan bertindak yang menilai sama hak dan kewajiban dirinya dan orang lain.

9. Rasa Ingin Tahu.

Sikap dan tindakan yang selalu berupaya untuk mengetahui lebih mendalam dan meluas dari sesuatu yang dipelajarinya, dilihat, dan di dengar.

10. Semangat Kebangsaan.

Cara berpikir, bertindak, dan berwawasan yang menempatkan kepentingan bangsa dan negara di atas kepentingan diri dan kelompoknya.

11. Cinta Tanah Air.

Cara berpikir, bertindak, dan berwawasan yang menempatkan kepentingan bangsa dan negara di atas kepentingan diri dan kelompoknya.

12. Menghargai Prestasi.

Sikap dan tindakan yang mendorong dirinya untuk menghasilkan sesuatu yang berguna bagi masyarakat, dan mengakui, serta menghormati keberhasilan orang lain.

13. Bersahabat/Komunikatif.

Sikap dan tindakan yang mendorong dirinya untuk menghasilkan sesuatu yang berguna bagi masyarakat, dan mengakui, serta menghormati keberhasilan orang lain.

14. Cinta Damai.

Sikap dan tindakan yang mendorong dirinya untuk menghasilkan sesuatu yang berguna bagi masyarakat, dan mengakui, serta menghormati keberhasilan orang lain.

15. Gemar Membaca.

Kebiasaan menyediakan waktu untuk membaca berbagai bacaan yang memberikan kebajikan bagi dirinya.

16. Peduli Lingkungan.

Sikap dan tindakan yang selalu berupaya mencegah kerusakan pada lingkungan alam di sekitarnya, dan mengembangkan upaya-upaya untuk memperbaiki.Hal inis angat penting mengingat bahwa siswa seringkali berinteraksi dengan masyarakat sekitar.

17. Peduli Sosial.

Sikap dan tindakan yang selalu ingin memberi bantuan pada orang lain dan masyarakat yang membutuhkan.

18. Tanggung Jawab.

Sikap dan perilaku seseorang untuk melaksanakan tugas dan kewajibannya, yang seharusnya dia lakukan, terhadap diri sendiri, masyarakat, lingkungan (alam, sosial dan budaya), negara dan Tuhan Yang Maha Esa.

Delapan belas nilai-nilai karakter diatas dapat menjadi fokus bagi guru untuk menanamkan nilai-nilai karakter pada setiap mata pelajaran yang ada di sekolah. Setiap nilai-nilai karakter yang akan ditanamkan kepada siswa, ada indikasi-indikasi yang harus diperhatikan, seperti contoh sikap peduli social, indiaksinya siswa dengan kesadaran sendiri membantuk temannya ketika mengalami permasalahan. 


\section{Strategi Penanaman Nilai-Nilai Karakter bagi Siswa Sekolah dasar dan Menengah}

Pendidikan karakter sebaiknya diajarkan secara sistematis dalam model pendidikan yang holistik menggunakan metode knowing the good, feeling the good, acting the good. Pengetahuan tentang kebaikan(knowing the good) mudah diberikan karena bersifat kognitif. Setelah knowing the good perlu ditumbuhkan perasaan senang atau cinta terhadap kebaikan (feeling the good).Selanjutnya, feeling the good diharapkan menjadi mesin penggerak sehingga seseorang secara suka reka melakukan perbuatan yang baik (acting the good). Penanaman dengan model seperti itu, akan mengantarkan seseorang kepada kebiasaan berlaku baik.

Akan tetapi, dalam penanaman pendidikan karakter yang utama adalah keteladanan.Orang tua memberikan contoh perilaku yang positif kepada anak-anaknya, guru memberi contoh kepada anak didiknya.Sementara itu, para pemimpin memberikan teladan karakter yang baik kepada masyarakat.

Masalah keteladanan ternyata dilakukan oleh para nabi, terutama Nabi Muhammad dalam menanamkan akhlak mulia kepada umatnya. Dalam hal ini, Allah menyatakan bahwa "Sungguh pada pribadi Nabi Muhammad terdapat teladan yang baik (uswatun hasanah)". Nabi-nabi yang lain seperti Nabi Ayub memiliki keteladan dalam ketabahannya menanggung berbagai penderitaan, Nabi Isa dikenal dengan kesederhanannya, Nabi Musa dikenal dengan kebeberaniannya.

Ada empat karakter yang dimiliki oleh para nabi, yaitu:

1. Sidik: selalu berkata yang benar;

2. Amanat: dapat dipercaya;

3. Tablig: selalu menyampaikan tidak pernah menyembunyikan;

4. Fatonah cerdas. Salah satu karakter yang sejak kecil melekat pada pribadi Muhammad adalah amanat (dapat dipercaya).

Oleh karenanya, masyarakat Arab memberikan gelar al amin (dapat dipercaya) jauh sebelum beliau menjadi nabi.Penanaman pendidikan karakter di sekolah dapat dilakukan dengan berbagai strategi. Strategi yang dapat dilakukan antara lain:

1. Memasukkan pendidikan karakter ke dalam semua mata pelajaran di sekolah

2. Membuat slogan-slogan atau yel-yel yang dapat menumbuhkan kebiasaan semua masyarakat sekolah untuk bertingkah laku yang baik

3. Membiasakan perlaku yang positif di kalangan warga sekolah, dan

4. Melakukan pemantauan secara kontinyu

5. Memberikan hadiah (reward) kepada siswa yang selalu berkarakter baik

Strategi penanaman karakter di atas merupakan hal yang sebenarnya sudah biasa dilaksanakan di sekolah, akan tetapi belum maksimal. Untuk itu dengan adanya nilai-nilai karakter sebagaimana uraian diatas dan strategi penanaman nilai-nilai karakter pada siswa sekolah dasar dan menengah, maka diharapkan dapat direalisasikan.

Peran dari kepala sekolah sebagai leader (kepemimpinan) dan harus mempunyai keterampilan manajerial dan akademik sangat diperlukan.Keterampilan manajerial lebih difokuskan pada administrasi dan pemberdayaan sumber daya yang ada di sekolah.Keteramilan akademik fokusnya yaitu bagaimana meningkatkan kualitas pendidikan yang ada di sekolah. 


\section{A. Kesimpulan}

\section{BAB III \\ KESIMPULAN DAN REKOMENDASI}

1. Nilai-nilai pendidikan karakter bagi siswa Sekolah dasar dan menengah yaitu: Religius, jujur, toleransi, disiplin, Kerja Keras, Kreatif, Mandiri, Demokratis, Rasa Ingin Tahu, Semangat Kebangsaan, Cinta Tanah Air, Menghargai Prestasi, Bersahabat/Komunikatif, Cinta Damai, Gemar Membaca, Peduli Lingkungan, Peduli Sosial.Tanggung Jawab.

2. Strategi dalam menanamkan nilai-nilai pendidikan karakter bagi siswa Sekolah dasar dan menengah yaitu: Memasukkan pendidikan karakter ke dalam semua mata pelajaran di sekolah, Membuat slogan-slogan atau yel-yel yang dapat menumbuhkan kebiasaan semua masyarakat sekolah untuk bertingkah laku yang baik, Membiasakan perlaku yang positif di kalangan warga sekolah, dan Melakukan pemantauan secara kontinyu, Memberikan hadiah (reward) kepada siswa yang selalu berkarakter baik

\section{B. Rekomendasi}

1. Peran seorang kepala sekolah yang mempunyai kompetensi akademik, dimana dapat menyusun program-program yang berkaitan dengan penanaman nilai-nilai pendidikan karakter bagi anak sekolah dasar dan menengah.

2. Guru harus memasukkan target-target karakter dalam setiap mata pelajaran, sehingga dalam proses pembelajaran guru tidak hanya fokus pada materi-materi yang bersifat kognitif, akan tetapi bagaimana nilai-nilai karakter yang harus ditanamkan pada siswa sekolah dasar dan menengah. 


\section{DAFTAR PUSTAKA}

Ahmadi, Abu, dan Priyono, Psikologi Belajar Jakarta: Rineka Cipta, 2006

Culbertson, S.S; Huffman, A.H; Alden-Anderson, R. (2010). Leader Member Exchange and Work-family Interactions: the Mediating Role of Self - Reported Challenge and Hindrance -Related Stress. The Journal of Psychology, 144.1, 15-36

Daniel N. 2007. Implementasi Pendidikan Karakter . Salemba Jaya. Jakarta

Dwi,K, Sigit.2007.Pentingnya Pendidikan Moral bagi anak Sekolah Dasar.Dinamika Pendidikan

Elmubarok. 2008. Pengantar Pendidikan Berbasis Karakter. Adi Karya : Yogyakarta.

Gunarto. 2004. Konsep Kurikulum di Indonesia. Rosda Karya : Bandung.

Hoover, Edwin A., Colette Lombard Hoover, 2000.Getting Along in Family Business The Relationship Intelligence Handbook, edisi bahasa Indonesia, PT. Raja Gravindo Persada, Jakarta.

Kidder, Louise, 1995.Research Method in Social Relation, Holt, Rineheart and Winston.

Narwanti, Sri. 2011. Pendidikan karakter. Yogyakarta : Familia

Priyono dan Maarif. 2010. Penyusunan Kurikulum Berbasis Pendidikan Karakter. Andi : Yogyakarta.

Samsuri.(2011). Pendidikan Karakter Warga Negara. Yogyakarta: Diandra. Pustaka

Sjarkawi. 2006. Pembentukan Kepribadian Anak. Jakarta: Bumi Aksara. Sukiman.

Sumiati. 2008. ... Kurikulum Pendidikan Agama Islam, Jakarta : Pustaka Jaya.

Superka. 2006. Konsep Dasar Pendidikan Karakter Anak Usia Sekolah. Andi : Yogyakarta.

Tim Pengembangan FIP-UPI. 2007. Panduan Pendidikan Karakter.Universitas Pendidikan Indonesia : Bandung.

Undang-Undang Republik Indonesia nomor 20 tahun 2003 tentang Sistem Pendidikan Nasional.

Winataputra Udin S. 2006. Konsep dan Strategi Pendidikan Kewarganegaraan di Sekolah: Tinjauan Psiko-Pedagogis (Paper). Pamulang. 